\title{
НИКОЛАЙ ПАВЛОВИЧ ПОДУШКИН - УЧЁНЫЙ, АРХЕОЛОГ, ЧЕЛОВЕК (к 90-летию со дня рождения)
}

\author{
(C) 2019 г. А.Н. Подушкин
}

В 2019 г. исполнилось 90 лет со дня рождения известного архелога Н.П. Подушкина. Творческий путь Николая Павловича начался в стенах КазПИ им. Абая. Первая полевая практика - участие в Южно-Казахстанской археологической экспедиции А.Н. Бернштама. Н.П. Подушкин работал в экспедициях А.Х. Маргулана в Центральном Казахстане, И.И. Копылова, Е.И. Агеевой, К.А. Акишева - в окрестностях АлмаАты, а также на юге и юго-востоке страны. В статье кратко изложены основные вехи творческого пути Н.П. Подушкина - от простого рабочего до начальника отряда и руководителя крупных археологических экспедиций. Второе призвание Н.П. Подушкина - педагогическая деятельность. В Чимкентском педагогическом институте, где он проработал с 1956 г., он вел такие ключевые курсы, как «Археология», «Историческое краеведение», «История древнего мира». Н.П. Подушкин - почетный гражданин г. Шымкента.

Ценность настоящей статьи заключается в том, что она снабжена редкими снимками, сделанными Н.П. Подушкиным на фотоаппарат «Зенит». Владению искусством фотографии Николая Павловича обучал в экспедициях А.Н. Бернштама известный в археологической науке специалист Л.И. Ремпель.

Ключевые слова: археология, Н.П. Подушкин, Южный Казахстан, КазПИ им. Абая, археолог, учитель-педагог, экспедиции

Николай Павлович Подушкин - известный ученый, археолог и педагог родился 1 января 1929 года в городе Талды-Курган, здесь же учился в средней школе им. Абая, которую окончил в 1948 г. По окончании школы Николай Павлович поступил на исторический факультет Казахского педагогического института имени Абая в городе Алма-Ата. Именно в стенах этого вуза молодой студент из глубинки приобщился к археологии. Вначале он был участником локальных экспедиций археологического отряда КазПИ под руководством Ивана Ивановича Копылова - педагога и исследователя, принимавшего активное участие в изучении памятников археологии округи Алма-Аты.

Но вскоре, причем уже по окончании первого курса, он оказался в рядах полевой археологической экспедиции, которую тогда возглавлял один из основоположников археологической науки в Казахстане Александр Натанович Бернштам. Способствовал этому опять же Иван Иванович Копылов, который в тот период, будучи аспирантом, контактировал с Александром Натановичем в Ленинграде и, поскольку А.Н. Бернштам набирал людей в поисковую археологическую экспедицию по средней Сырдарье, он рекомендовал туда Николая Павловича.

Вот таким образом в составе Южно-Казахстанской археологической экспедиции Н.П. Подушкин начал свой длинный и плодотворный научный и практический путь в археологии Казахстана вначале в качестве простого рабочего, затем - начальни- 
Подушкин A.H. Николай Павлович Подушкин - учёный, археолог, человек

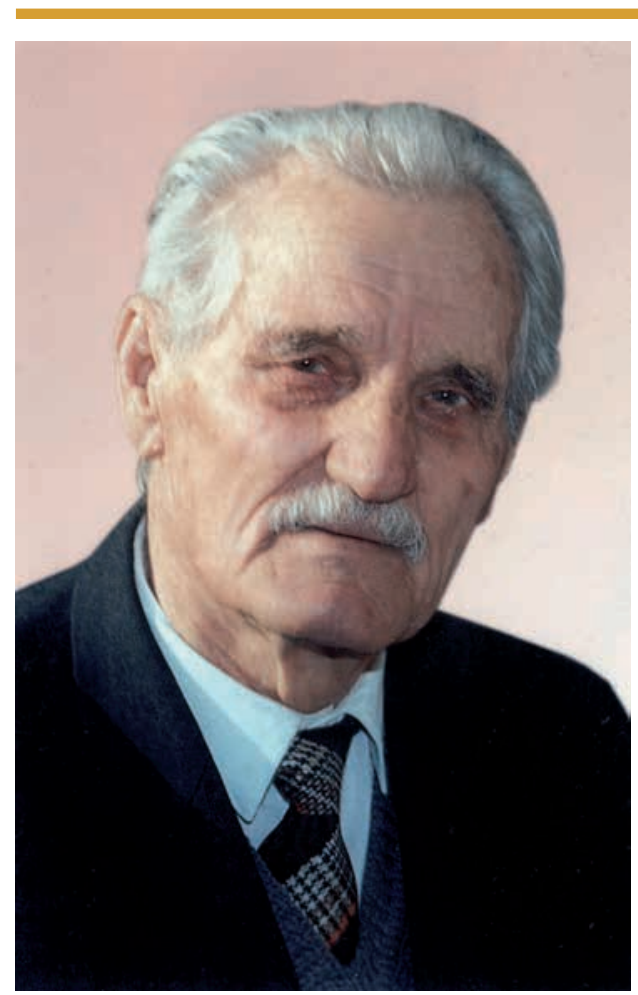

Рис. 1. Николай Павлович Подушкин. 20.01.2004

Fig. 1. Nikolay P. Podushkin. 20.01.2004

ка отряда и руководителя крупных археологических экспедиций.

Этапы этого пути отмечены следующим образом.

В 1949-1950 годах он был участником ЮКАЭ под руководством А.Н. Бернштама, которая обследовала регион на предмет первоначального изучения археологических объектов бассейна Сырдарьи (от впадения в эту реку р. Келес и до Отрарского оазиса включительно). Результатом стало выявление в этой зоне большого числа памятников городской культуры, часть которых подверглась топографической съемке, картографической фиксации, рекогносцировочным и стратиграфическим раскопкам (у Чардары - городище Актобе и могильник Узун-Ата, в Отрарском оазисе - городища Отрартобе, КокМардан, Куйруктобе, Мардан-Куик, городище Алтынтобе и др.).
В полевых сезонах 19501951 годов Николай Павлович работал в составе Центрально-Казахстанской археологической экспедиции под руководством Алькея Хакановича Маргулана, которая исследовала памятники андроновской культуры эпохи бронзы. Были открыты и частично подвергнуты раскопкам могильники андроновской культуры по рекам Нура, Шерубай-Нура. Параллельно в 1950-1952 годы Н.П. Подушкин участвует в экспедициях ЮКАЭ под руководством А.Н. Бернштама, которая расширяет свои исследования в Южном Казахстане, включая объекты ранней городской культуры и погребальные памятники бассейна p. Арысь: проводятся рекогносцировочные и стационарные раскопки городища Жуантобе, вскрываются погребальные сооружения могильника Борижар.

В 1954-1955 годы в составе ЮКАЭ под руководством А.Н. Бернштама и Е.И. Агеевой Николай Павлович исследует городскую культуру Баба-Атинского оазиса (зона гор Каратау, Сузакский р-н ЮКО); здесь же он становится руководителем раскопок могильника эпохи бронзы ТауТары, а также работает в составе рекогносцировочного отряда, который вел раскопки шурфа на городище Кумкент.

Надо сказать, что участие в экспедициях конца 1940-х - начала 1950-х годов, где руководители и коллективы представляли собой исключительно интеллектуальное сообщество (чего стоят только имена А.Н. Бернштама, А.Х. Маргулана, Е.И. Агеевой, К.А. Акишева и др.), сформировали Николая Павловича не только как человека, но и профессионального ученого, который знания и навыки, приобретенные в полевых экспедициях, использовал на протяжении всей своей жизни. Например, уже тогда он научился фотографировать (и освоил все стадии получения 


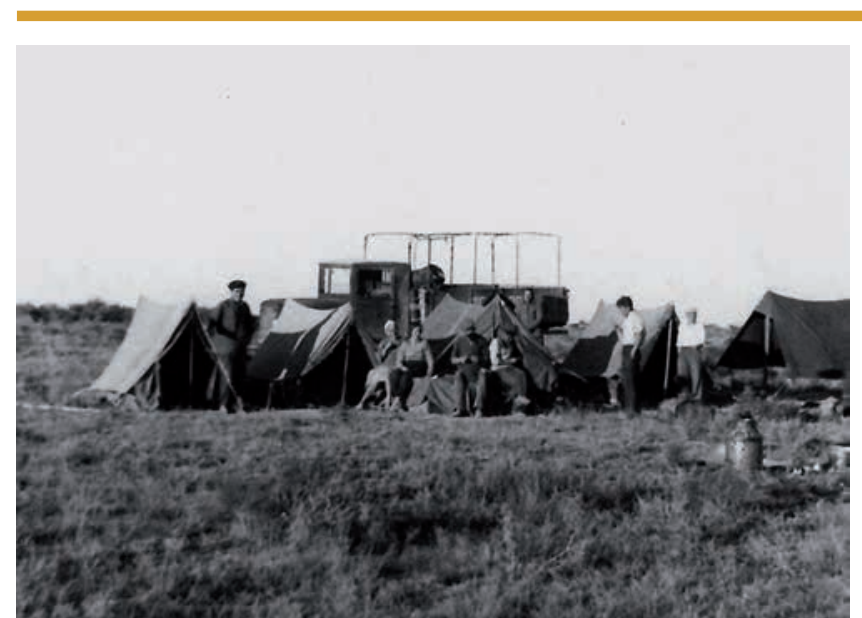

Рис. 2. ЮКАЭ-1949. Археологический лагерь на Сырдарье, ур. Каинда-Тогай.

Крайний справа у палатки - И.И. Копылов

Fig. 2. SKAE-1949. Archaeological camp on the Syr Darya, mountain area Kainda-Togay. Rightmost at a tent - I.I. Kopylov где фигурируют галереи личностей, стоящих $\mathrm{y}$ истоков казахстанской археологии, бытовые и рабочие моменты.

Свою поисковую археологическую деятельность Н.П. Подушкин успешно сочетал с научно-педагогической: в 1952-1955 годах он аспирант по специальности «История» КазПИ им. Абая, а с 1953 г., по окончании института и соответствующего распределения, он начинает свою трудовую деятельность в качестве учителя истории средней образовательной фотографий) и активно применял свое умение на практике, что для полевой археологии, где элемент фиксации всех циклов работ обязателен, немаловажно. Кажется, к этому искусству его приобщил известный ученыйискусствовед Лазарь Израилевич Ремпель, который был участником бернштамовских экспедиций.

Сложно сказать, каким образом у очень скромно одетого и малообеспеченного материально студента появился фотоаппарат (по тем временам вещь достаточно дорогая), но почти всегда Николай Павлович был со знаменитым в те годы пленочным «Зенитом», которым много фотографировал. В результате сейчас мы имеем почти бесценные черно-белые фотографии жизни, работы археологических экспедиций конца сороковых - начала пятидесятых годов XX века,

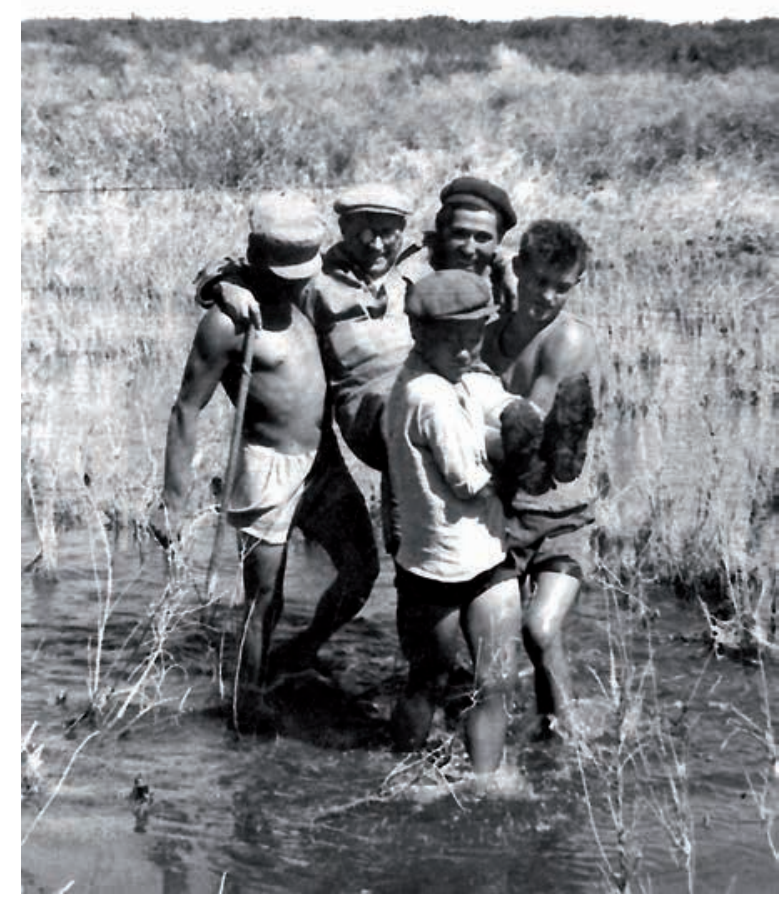

Рис. 3. ЮКАЭ-1949. Городище Кок-Мардан (Отрарский оазис). А.Н. Бернштам форсирует ров. Крайний справа - Н.П. Подушкин

Fig. 3. SKAE-1949. Ancient settlement Kok Mardan (Otrar oasis). A.N. Bernshtam crosses a ditch. Rightmost-N.P. Podushkin 
Подушкин A.H. Николай Павлович Подушкин - учёный, археолог, человек

школы № 8 им. Ленина (г. Шымкент; ныне колледж им. М.Х. Дулати). С 1956 г. Николай Павлович переходит работать в Чимкентский педагогический институт (ЧПИ), это образовательное учреждение на долгие годы станет местом приложения его педагогических и научных усилий: здесь в 1964 г. он основывает Археологический отряд ЧПИ, который успешно функционирует и поныне, являясь одним из немногих в Казахстане отрядов, более полувека ведущих исследования. Именно с полевой деятельностью

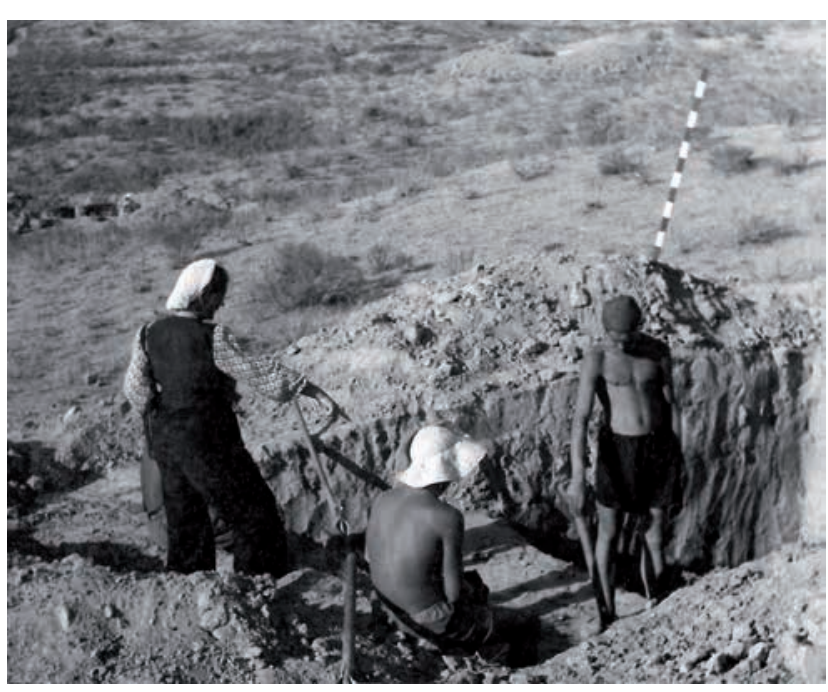

Рис. 4. ЮКАЭ-1949-1953. Борижар.

Е.И. Агеева на раскопе склепа-науса.

Fig. 4. SKAE-1949-1953. Borijar.

E.I. Ageeva on the crypt-naus excavation этого отряда связана ключевая тематика научных интересов Н.П. Подушкина: он планомерно, на долгосрочной основе стал изучать оседло-земледельческие поселения верхнего и среднего течения реки Арысь.

Начались раскопки первых эталонных объектов арысской культуры Южного Казахстана (1964-1968 гг.: поселение Караултобе, Наймантобе; 1968-1970 гг.: городище Торткультобе и др.). Результатом этих усилий стала успешная защита диссертации на соискание ученой степени кандидата исторических наук на тему: «Ранние оседлые поселения долины Арыси (I-VIII вв.)» (Алма-Ата, 1970 г.; научный руководитель К.А. Акишев) [Подушкин Н.П., 1970а, 1970б].

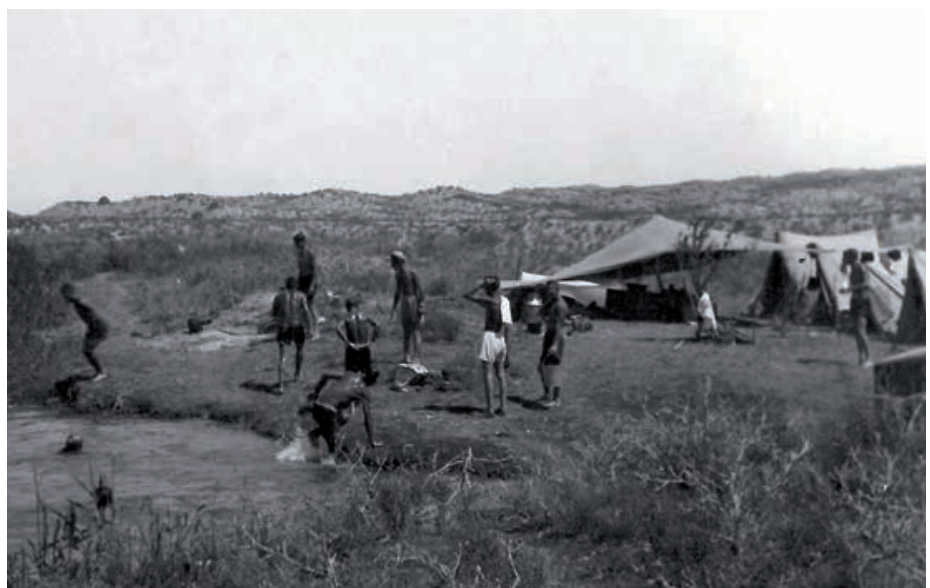

Рис. 5. ЮКАЭ-1950. Борижар. Археологический лагерь. Человек с полотением - К.А. Акишев

Fig. 5. SKAE-1950. Borijar. Archaeological camp. The person with a towel is K.A. Akishev 


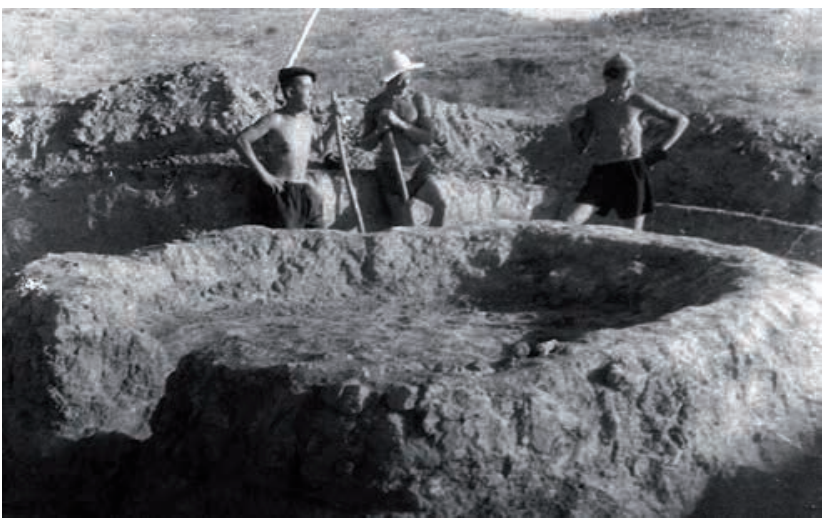

Рис. 6. ЮКАЭ-1950. Борижсар. Раскопки науса. В ичентре - Г.А. Кушаев

Fig. 6. SKAE-1950. Borijar. Excavation of a naus. In the center - G.A. Kushayev

с другими образовательными, музейными и общественными учреждениями города («Детская туристическая станция им. Терешковой», «ЮжноКазахстанский областной историкокраеведческий музей», «Общество охраны памятников истории и культуры», средние школы города и области) [Подушкин Н.П., 1990; Подушкин Н.П., Подушкин А.Н., 2003].

Он часто встречается с учителями, школьниками, читает лекции на историкокультурную тематику, организовывает в стенах некоторых школ и учреждений краеведческие уголки и музеи (СШ № 8; 5 ; детская туристическая станция). Аналогичный археологический центрмузей он создает в ЧПИ, и этот центр на многие годы становится своеобразной первоначаль - ной «кузницей кадров» в сфере региональной археологии: здесь студенты получали представление о полевой, камеральной и кабинетной археологии, писали рефераты, дипломные работы на археологическую тематику.

Благодаря усилиям Николая Павловича и его научным связям многие из них вышли на республиканский и всесоюзный уровень. Например, начиная с 1968 г., студенты из Южного Казахстана впервые (а затем - на годы вперед) становятся участниками Всесоюзной археологической студенческой конференции в Москве, а также - участниками многочисленных региональных археологических студенческих конференций (Алма-Ата, Ташкент, Ашхабад).

Многие выпускники исторического факультета ЧПИ (и нынешний директор Института археологии им. А.Х. Маргулана, д.и.н. Байтанаев Б.А.) посредством археологической

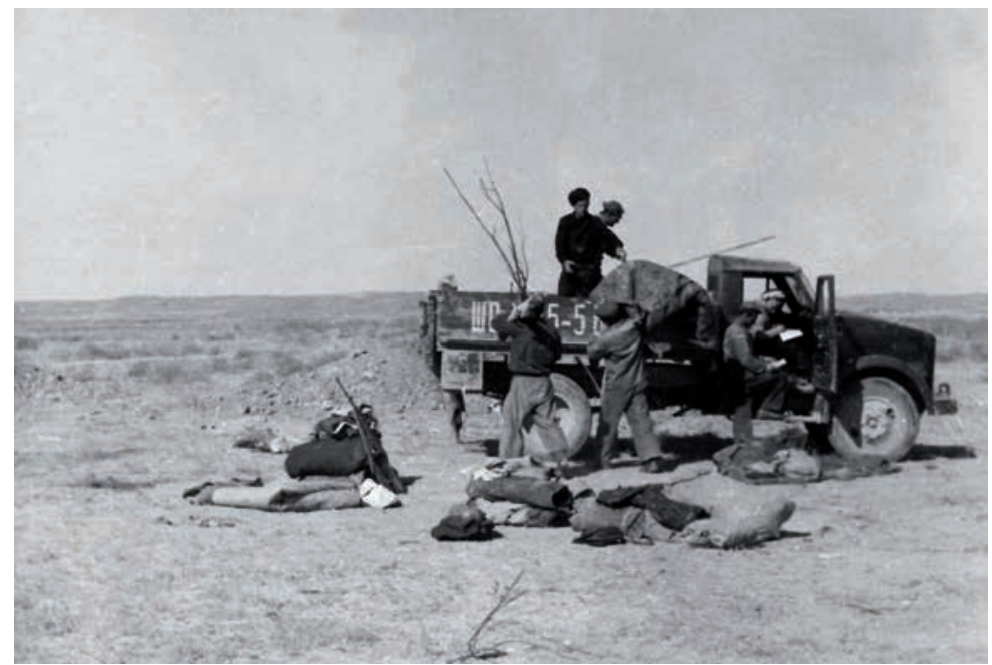

Рис. 7. ЮКАЭ-1950. Чардара. Сбор лагеря. В кузове машинь - Н.П. Подушкин, в кабине - Е.И. Агеева

Fig. 7. SKAE-1950. Chardara. Camp packing. In the car body-N.P. Podushkin, in the cabin-E.I. Ageeva 
Подушкин А.H. Николай Павлович Подушкин - учёный, археолог, человек

практики оказались причастны к древней истории и в реалии соприкоснулись с полевой археологией; некоторые из них на определенный срок сделали археологию сферой применения своих профессиональных интересов, часть стала работать в учреждениях, так или иначе связанных с археологией и историей родного края. В их числе А.Н. Подушкин, А.А. Рустемов, А.Г. Донец, А.С. Мирзабаев, А.Н. Грищенко, П. Каратаев, А.А. Ержигитова и другие.

В 1970-1977 гг. как руководитель археологического отряда Чимкентского пединститута Н.П. Подушкин ведет раскопки цитадели городища Шымкент, затем - поселения Бургулюк, а также городища Отрартобе и Пшук-Мардан.

В 1978-1979 гг. Николай Павлович включается в охранные археологические работы регионального уровня, связанные со строительством в Южном Казахстане ирригационных сооружений. Осуществляются раскопки раннего поселения Актобе Чаянское, которое попадает в зону зато-

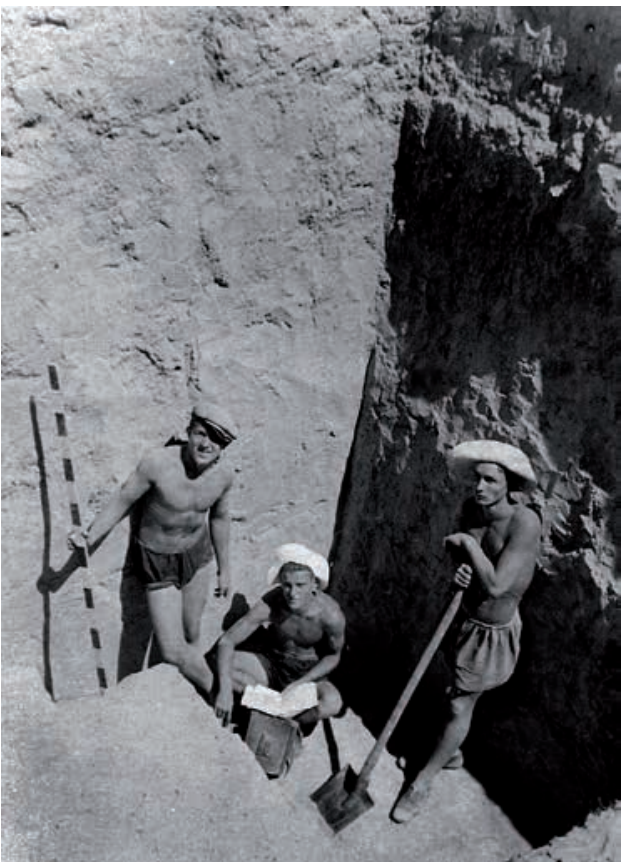

Рис. 8. ЮКАЭ-1950. Борижар, у с. Мамаевка. Раскопки катакомбы. В ичентре - Н.П. Подушкин

Fig. 8. SKAE-1950. Borijar, at the village of Mamayevka. Excavation of a catacomb. In the center - N.P. Podushkin

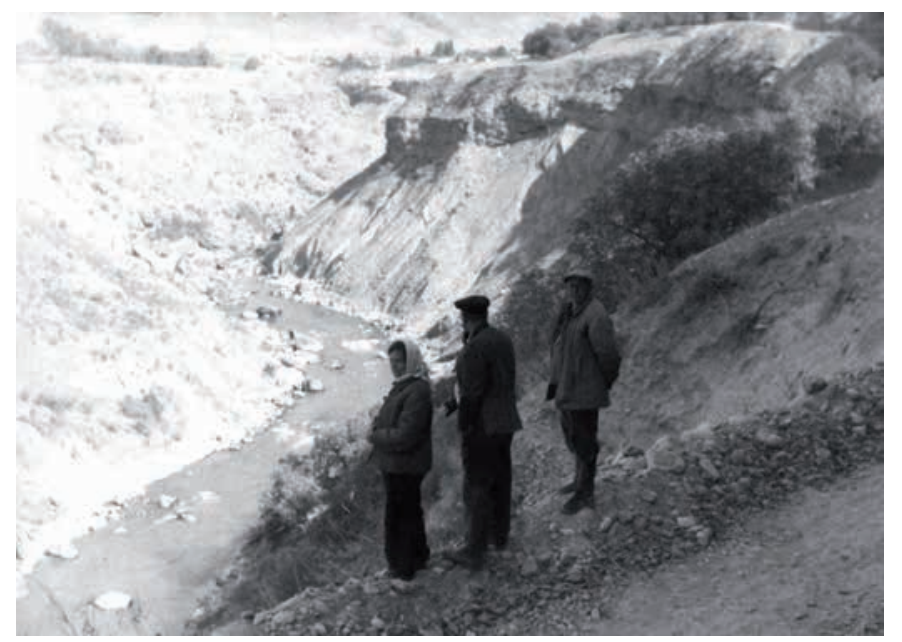

Рис. 9. ЮКАЭ-1950. Река Пскем у пос. Богустан (Бостандыкский р-н). Слева направо: Е.И. Агеева, А.Н. Бернштам, Г.И. Пацевич

Fig. 9. SKAE-1950. The Pskem River at the settlement of Bogustan (Bostandyk district). From left to right: E.I. Ageeva, A.N. Bernshtam, G.I. Patsevich пления Капчагайского водохранилища (Байдибекский р-н ЮКО) а также городища Майтобе и нескольких погребальных памятников номадов позднего железного века, попавших в зону ирригационного освоения в Сузакском районе ЮКО.

Большая работа была проделана Н.П. Подушкиным в рамках проекта по паспортизации археологических объектов Южно-Казахстанской области: с 1984 по 1992 гг. вместе с А.Н. Подушкиным он руководил отрядом по 


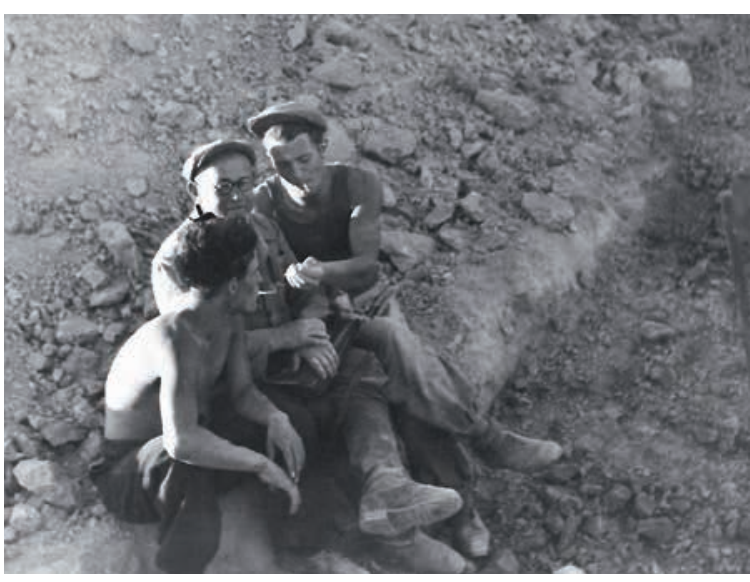

Рис. 10. ЮКАЭ-1950. Городище Кок-Мардан. Беседа. Слева - Н.П. Подушкин, в центре - Г.И. Пацевич

Fig. 10. SKAE-1950. Ancient settlement Kok Mardan. Conversation. At the leftN.P. Podushkin, in the center - G.I. Patsevich

выявлению, первоначальному обследованию, картографированию и сбору информации о памятниках археологии Южно-Казахстанской области, что впоследствии стало основой для издания «Свода памятников истории и культуры Казахстана. ЮжноКазахстанская область. Т. I» (АлмаАта, 1994).

Николай Павлович Подушкин стоял у истоков исследования ранних земледельческих памятников бассейна Арыси и Средней Сырдарьи (городищ, поселений, погребальных сооружений), составивших источниковую базу арысской культуры Южного Казахстана IV в. до н.э. - IV в. н.э.

Педагогическая деятельность Н.П. Подушкина продолжилась и после выхода на пенсию: в 1998 году в должности доцента он покинул ЧПИ и стал работать профессором кафедры «История Казахстана» в университете «МИРАС» (г. Шымкент), в котором он преподавал до того момента, когда болезнь и почтенный возраст не стали серьезными препятствиями и по состоянию здоровья он вынужден был прекратить работу (2010 г.).

Отдельное место в жизни Н.П. Подушкина занимала общественная деятельность. Он стоял у истоков создания «Славянского культурного Центра» в Южном Казахстане, несколько лет был его председателем. В девяностые годы такая работа требовала определенного мужества, так как не все правильно понимали консолидирующую роль национальных культурных центров в формировании толерантного интернационального общества современного Казахстана. И только через два десятилетия культурные национальные центры заняли свое достойное место в социуме нашего государства в рамках Большой и Малой Ассамблей народов Казахстана как инструменты предсказуемой национальной политики.

Работал он и в ономастической комиссии Южно-Казахстанского областного акимата, на заседаниях ко-

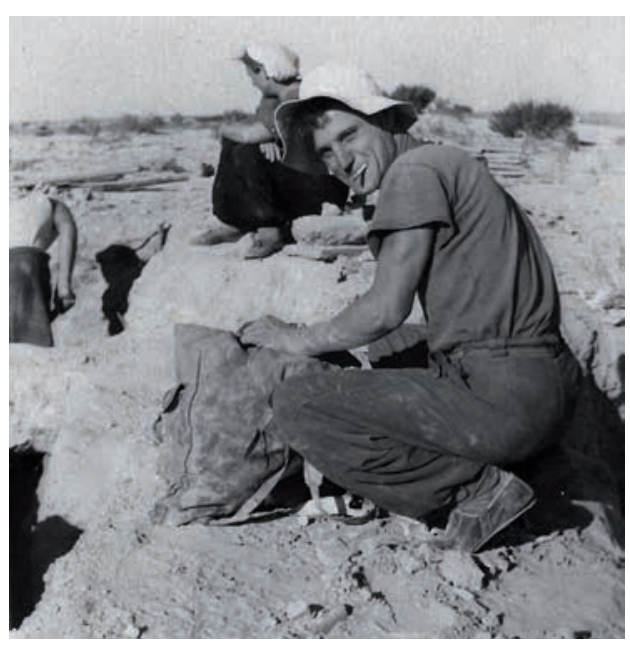

Рис. 11. ЮКАЭ-1951. Городище КокМардан (Отрарский оазис). В кадре: Н.П. Подушкин, за ним - Е.И. Агеева

Fig. 11. SKAE-1951. Ancient settlement Kok Mardan (Otrar oasis). In a shot: N.P. Podushkin, behind it - E.I. Ageeva 
Подушкин А.H. Николай Павлович Подушкин - учёный, археолог, человек

торой пытался научно обосновать и аргументировать необходимость сохранения истинно народных названий топонимов, гидронимов и оронимов без крена в беспредельный антропонимизм местечкового кланового происхождения.

Н.П. Подушкин как творческая личность знал и любил восточную поэзию, глубоко разбирался в истории, литературе и религии арабского мира. На столе у него часто можно было видеть томики стихов Омара Хайяма, горы литературы по исламу. Он никогда не был воинствующим атеистом

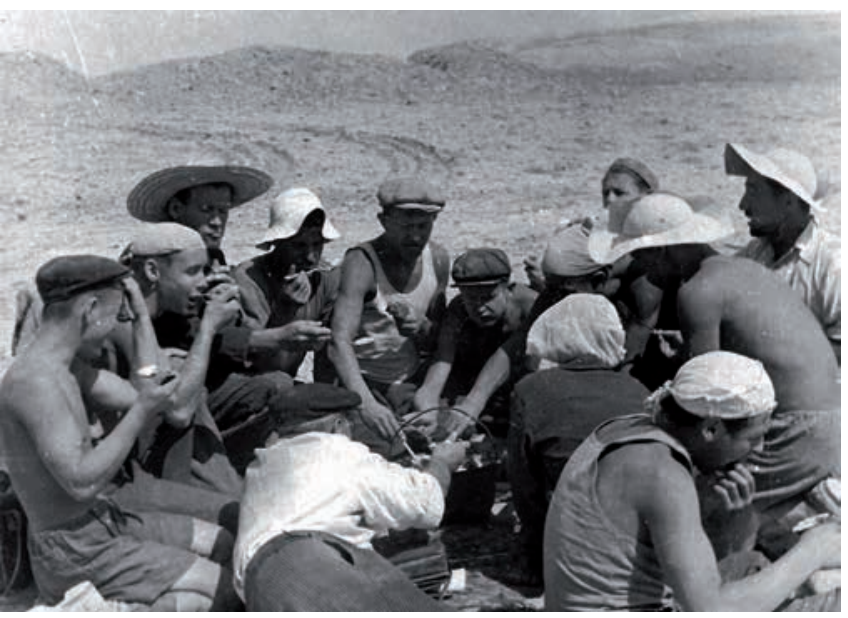

Рис. 12. ЮКАЭ-1951. Городище Кок-Мардан (Отрарский оазис). Холодный обед. В кадре: А.Н. Бернштам (полулёэа спиной);

Е.И. Агеева (в платке, спиной); Л.И. Ремпель, А.М. Оразбаев, М. Морозов

Fig. 12. SKAE-1951. Ancient settlement Kok Mardan (Otrar oasis). Cold lunch. In a shot: A.N. Bernshtam (semi-lying back); E.I. Ageeva (wearing a scarf, back); L.I. Rempel, A.M. Orazbayev, M. Morozov (что ему часто приписы-

вают), наоборот - популяризировал светское научное понимание великих монотеических религий мира на уровне изучения истории появления, развития этих религий (в том числе

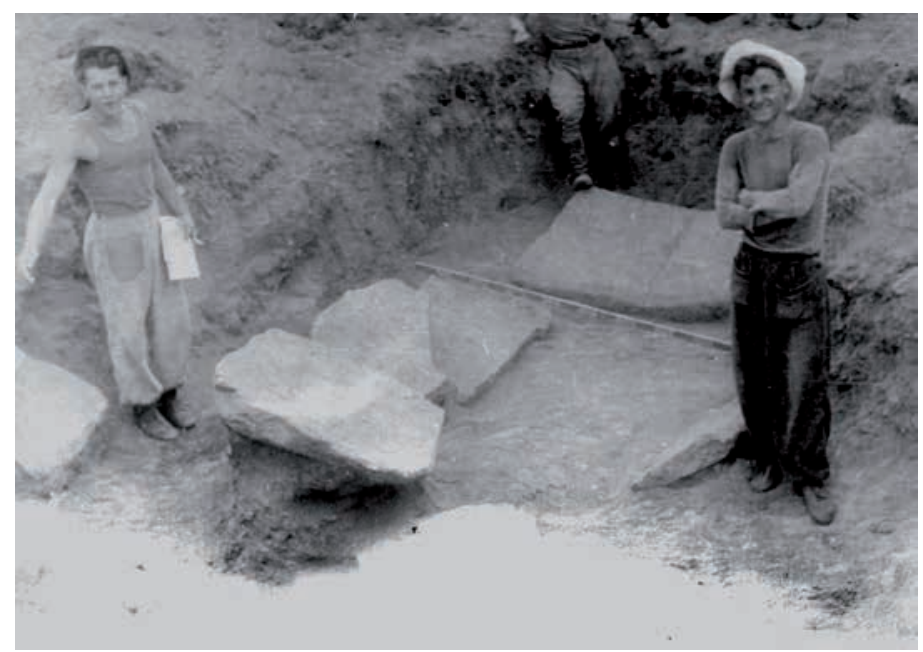

Рис. 13. ЦКАЭ-1951. Могильник андроновской культуры на р. Шерубай-Нура. Н.П. Подушкин-справа

Fig. 13. CKAE-1951. The burial ground of Andronov culture on the Sherubay-Nura River. N.P. Podushkin - on the right ислама), что нашло отражение в его последних публикациях. Совершенно естественно такая позиция кардинально расходилась с теологической точкой зрения и заканчивалась выраженным неприятием и «навешиванием ярлыков» вплоть до обвинения в экстремизме (!).

Самым тесным образом контактировал Николай Павлович с коллективом и администрацией ЮжноКазахстанского областного историкокр а ев е д ч с кого музея. С момента переезда музея в новое здание Николай Павлович уделял много личного времени, выступая в роли консультанта 
по становлению экспозиции, формированию фондов музея - более того, большое количество артефактов, полученных в ходе археологических исследований, он передал музею. Здесь же он часто читал публичные лекции перед общественностью города, области и даже - проводил занятия, практику со студентами исторического факультета.

Между тем значительная часть коллекции из раскопок ранних поселений арысской культуры (поселения Караултобе, Торткультобе) хранится в Центральном Государственном музее Республики Казахстан (г. Алматы), а наиболее уникальные артефакты выставлены в основной экспозиции. Впоследствии по инициативе директора Центрального музея Республики Казахстан Нурсана Алимбая при этом учреждении был организован персональный фонд Николая Павловича и Александра Николаевича Подушкиных, который ежегодно пополняется новыми коллекциями и находками.

Николай Павлович по настоящему дружил с прессой, до конца своих дней он был внештатным корреспондентом областной общественнополитической газеты «Южный Казахстан», в которой публиковались за

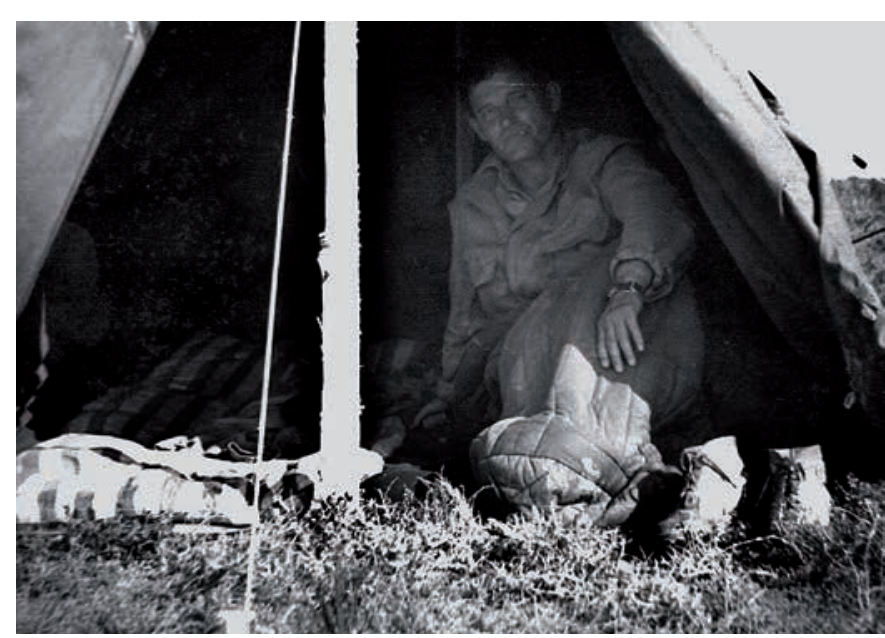

Рис. 15. Н.П. Подушкин, 1968. Торткультобе (Кумышка)

Fig. 15. N.P. Podushkin, 1968. Tortkultobe (Kumyshka)

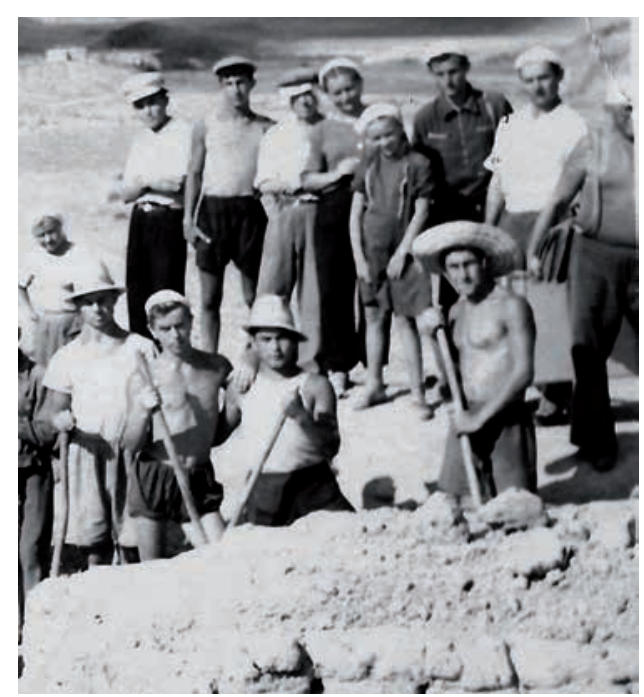

Рис. 14. ЦКАЭ-1954. Городище Баба-Ата. В иентре - Е.И. Агеева с дочерью Татьяной, рядом - Н.П. Подушкин

Fig. 14. CKAE-1954. Ancient settlement Baba-Ata. In the center-E.I. Ageeva with daughter Tatyana, nearby - N.P. Podushkin

многие годы огромное количество его статей, посвященных археологической, историко-культурной и охранной проблематике нашего края.

Его человеческие, профессиональные качества высоко ценили все крупные исследователи, стоявшие у истоков археологической и исторической школ Казахстана, как старшее поколение в лице А.Н. Бернштама, A.X. Маргулана, Г.И. Пацевича, Е.И. Агеевой, К.А. Акишева, Г.А. Кушаева, А.М. Оразбаева, последующее в лице М.К. Кадырбаева, К.М. Байпакова, Л.Б. Ерзаковича, C.M. Ахинжанова, Б.Н. Нурмуханбетова, А.Г. Медоева, В.А. Грошева, А.Г. Максимовой, Б.Т. Туякбаевой, так и современное в лице 3. Самаше- 
Подушкин А.H. Николай Павлович Подушкин - учёный, археолог, человек

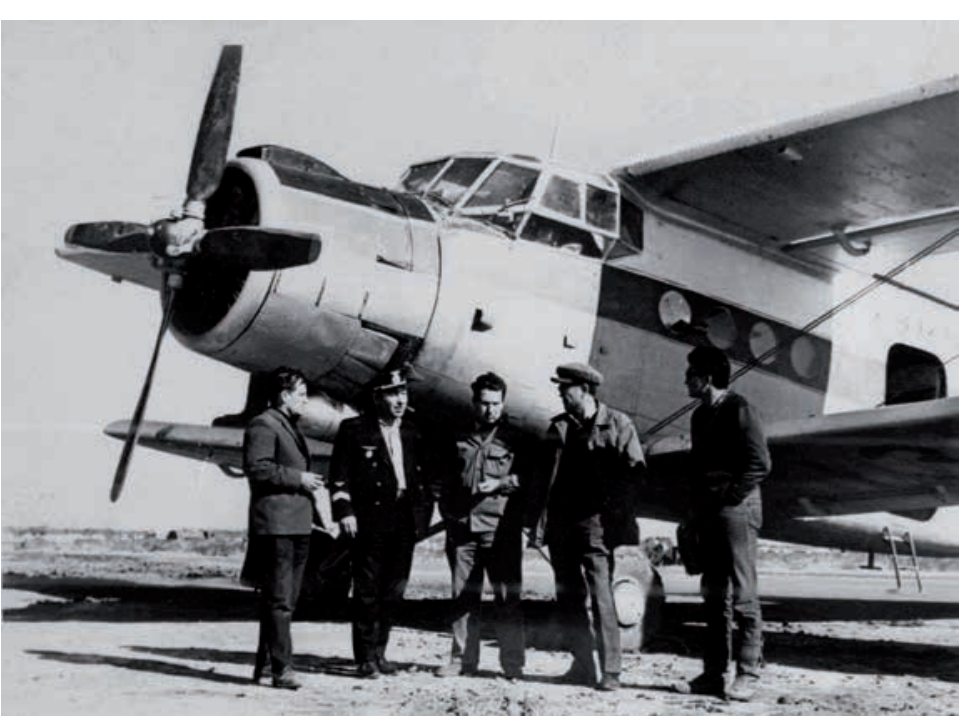

Рис. 16. Отрар, октябрь 1969. Слева направо: Н.П. Подушкин, второй и третий - члены экипажа, К.А. Акишев, К.М. Байпаков

Fig. 16. Otrar, October, 1969. From left to right: N.P. Podushkin, the second and third-crew members, K.A. Akishev, K.M. Baipakov
Н.П. Подушкин был прекрасным семьянином, ценности семьи для него всегда были основополагающими; не случайно поэтому он прожил счастливой семейной жизнью со своей супругой Раисой Игнатьевной более 60 лет. Очевидно, такая позитивная обстановка в семье предопределила еще одно качество - почти безмерное гостеприимство дома Подушкиных в Шымкенте.

Без преувеличения можно скава, В.Ф. Зайберта, А.Н. Марьяшева, М.К. Хабдулиной, Ф.П. Григорьева, Б.А. Байтанаева, М. Кожа, А.К. Акишева и других.

Знали Николая Павловича археологи и ученые ближнего и дальнего зарубежья: Л.И. Ремпель (Узбекистан), Л.М. Левина (Россия), Ф. Грене (Франция), Р.X. Сулейманов (Узбекистан), Б.А. Раев (Россия). Со многими из казахстанских археологов Николая Павловича связывали не только профессиональные интересы, но и многолетняя дружба. Особенно это касается взаимоотношений с К.А. Акишевым, искренние и теплые отношения с которым поддерживались более полувека.

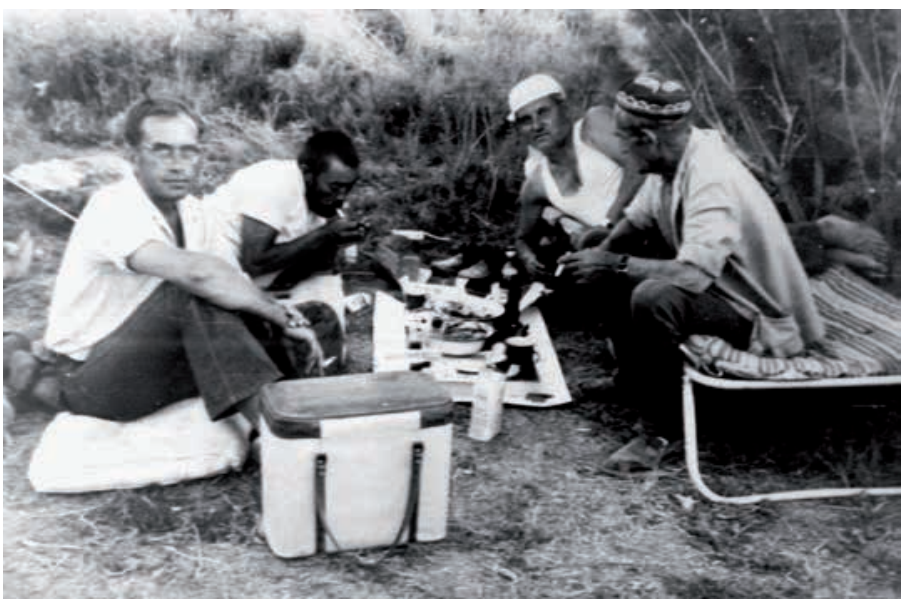

Рис. 17. Пиук-Мардан, 1977. Слева направо: Л. Ерзакович, Б. Нурмуханбетов, Н. Подушкин, неизвестный

Fig. 17. Pshuk-Mardan, 1977. From left to right: L. Erzakovich, B. Nurmukhanbetov, N. Podushkin, unknown 
имел значения): всегда всем хозяин и хозяйка находили уголок для отдыха, предлагали хороший стол-дастархан и создавали дружественную интеллектуальную атмосферу для позитивного общения. Не миновали этот гостеприимный дом и другие крупные казахстанские исследователи и общественные деятели: здесь были Нурбулат Масанов, Мурат Ауэзов.

Н.П. Подушкин был человеком своего времени, и как гражданин той эпохи он прошёл все ступени становления, расцвета и полного краха советско-коммунистического строя. Он искренне верил в идеалы марксистко-ленинской идеологии, был членом КПСС, и даже определенное время возглавлял партийную организацию факультета ЧПИ. На этот счет у него были свои принципы и твердые убеждения, которым он никогда не изменял - видимо, поэтому после развала Советского Союза в начале девяностых годов XX века он не рвал и публично не сжигал свой партийный билет, а также не выливал моря негатива и грязи на советскосоциалистическое прошлое, как это делали и до сих пор делают некоторые «истинные партийцы», стоявшие у руля государства много лет и в одночасье потерявшие к нему интерес после того, как оно перестало обеспечивать их высокий достаток.

Будучи личностью сильной, он воспринял все произошедшее как историческую данность, хотя, как и миллионы советских людей с чистой совестью, сильно переживал. У него нашлись силы адаптироваться к новым условиям жизни, он продолжал интенсивно работать, несмотря на большие проблемы со здоровьем: после обширных инфарктов Николай Павлович дважды смотрел смерти в лицо, но судьба сохранила ему жизнь.

Что касается работы, то он действительно был работо-голиком, причем никогда не требовал в отношении себя каких-либо преференций: буду- чи уже в почтенном возрасте, всегда аккуратно одетый, на работу он ходил пешком или ездил на городском транспорте; при этом практически никогда не опаздывал на лекции или общественные мероприятия. Насколько Николай Павлович любил свою работу, студентов, школьников и насколько ею дорожил свидетельствует такой факт: после наступления пенсионного возраста он три года (!) не оформлял документы на получение законной пенсии, считая, что он абсолютно работоспособный человек и пенсия ему просто не нужна. В наше время очень сложно представить, чтобы человек добровольно на достаточно длительный срок отказался от причитающейся ему пенсии, но этот реальный эпизод лишь подчеркивает полное отсутствие у Николая Павловича такого социально опасного явления как меркантилизм.

При всех положительных качествах Николай Павлович не был «легким» человеком - и в семье, и в обществе. Напротив, его внешний вид, сдержанная манера общения (он всегда, что называется, «держал дистанцию» и никогда не позволял собеседнику в отношении себя вольных формулировок или панибратства) создавали впечатление интеллектуальной сложной личности, не очень «удобной» и даже суровой.

Он имел свою точку зрения на все жизненные явления, которая зачастую расходилась с общепринятой, и практически не менял её, как и модель своего социального поведения: всегда держал слово, принятых стратегических решений также не менял, близко не подпускал к себе людей непорядочных, грязных на руку или хоть отдаленно причастных к коррупционным действиям. Видимо, поэтому сейчас фамилия «Подушкин» в студенческой и общественной среде нескольких поколений шымкентцев ассоциируется с подлинно чистой совестью, на которой нет никаких темных пятен. 
Николай Павлович Подушкин как ученый-археолог является автором многих публикаций на археологическую, историко-культурную тематику, в их числе четыре монографии, он - Почетный гражданин города Шымкента, награжден государственными наградами.

\section{Список основных трудов Н.П. Подушкина}

Свод памятников истории и культуры Казахстана. Южно-Казахстанская область. Алма-Ата: Энциклопедия, 1994. Т. І. 367 с. (в соавт. с К.М. Байпаковым, А.Н. Подушкиным и др.).

Очерки по истории и культуре Казахстана. Алматы: «Казакпарат», 2003. 380 с. (в соавт. с А.Н. Подушкиным).

История мировых религий. Алматы: «Арман-ПВ», 2012. 214 с. (в соавт. с А.Н. Подушкиным).

Религиоведение (факультативный курс). Учебная программа, 9 класс. Алматы: «Арман-ПВ», 2009. 20 с. (в соавт. с А.Н. Подушкиным).

Новое поселение раннеземледельческой культуры на юге Казахстана // Известия АН КазССР. Сер. обществ. наук. 1968. № 5. С. 71-75.

К вопросу о керамике раннеземледельческих поселений верховий реки Арысь (I-IV вв.) // По следам древних культур Казахстана. Алма-Ата: Наука КазССР, 1970. C. $93-107$.

Торткультобе - памятник оседлой культуры долины Арыси V-VIII вв. // Материалы научной конференции Чимкентского пединститута. Чимкент, 1970. 6 с.

Гончарные печи раннеземледельческих поселений долины Арыси (Южный Казахстан) // Археологические исследования в Казахстане. Алма-Ата: Наука КазССР, 1973. С. $183-187$.

О хозяйстве оседлого населения Арыси в I-IV вв. н.э. // В глубь веков. АлмаАта: Наука КазССР, 1974. С. 78-84. C. 440 .

Археологическая разведка в Чимкентской области // АО-1980. М.: Наука, 1981.

Раскопки поселения-убежища в ущелье Бургулюк // Средневековая городская культура Казахстана и Средней Азии. Алма-Ата: Наука КазССР, 1983. С. 177-181.

Памяти Кималя Акишевича Акишева // Мобилизованный археологией. Астана: Евразийский национальный университет им. Л.Н. Гумилева, 2004. С. 59-60.

\section{ЛИТЕРАТУРА}

1. Подушкин Н.П. Ранние оседлые поселения Арыси (I-VIII в.в.): автореф. дис. ... канд. ист. наук. Алма-Ата: Институт истории, археологии и этнографии им. Ч.Ч. Валиханова, 1970. 19 с.

2. Подушкин Н.П. Ранние оседлые поселения Арыси (I-VIII в.в.): дис. ... канд. ист. наук. Алма-Ата: Институт истории, археологии и этнографии им. Ч.Ч. Валиханова, 1970. $183 \mathrm{c.}$

3. Подушкин Н.П. Археологические памятники Чимкентской области. Чимкент, 1990. 20 с.

4. Подушкин Н.П., Подушкин А.Н. Очерки по истории и культуре Казахстана. Алматы: «Казакпарат», 2003. 380 с.

\section{Сведения об авторе:}

Подушкин Александр Николаевич - доктор исторических наук, профессор, Южно-Казахстанский государственный педагогический институт (г. Шымкент, Казахстан); p_a_n_alex@mail.ru 


\section{НИКОЛАЙ ПАВЛОВИЧ ПОДУШКИН - \\ ҒАЛЫМ, АРХЕОЛОГ, АДАМ \\ (туғанына 90 жылдығына орай)}

\section{А.Н. Подушкин}

2019 ж. танымал археолог Н.П. Подушкинннің туылғанына 90 жыл толып отыр. Николай Павловичтің шығармашылық жолы Абай атындағы Қазақ педагогикалық институтының қабырғасында басталды. Алғашқы далалық тәжірибесі - А.Н. Бернштамның Оңтүстік Қазақстан архелогиялық экспедициясына қатысуы. Н.П. Подушкин Ә.Х. Марғұланның Орталық Қазақстан, И.И. Копыловтің, Е.И. Агееваның, К.А. Ақышевтің - Алматы маңындағы, сондай-ақ еліміздің оңтүстік және оңтүстік-шығысындағы экспедицияларда жұмыс істеді. Мақалада Н.П. Подушкиннің шығармашылығының негізгі кезеңдері - қарапайым жұмысшыдан ipi археологиялық экспедиция жетекшілігіне дейінгі қызметтері қысқаша айтылған. Н.П. Подушкиннің екінші бейімділігі - педагогикалық қызмет. 1956 жылдан бастап жұмыс істеген Шымкент педагогикалық институтында «Археология», «Тарихи өлкетану», «Ежелгі дүние тарихы» секілді негізгі пәндерді жүргізді. Н.П. Подушкин - Шымкент қаласының құрметті азаматы.

Мақаланың басты құндылығы Н.П. Подушкиннің «Зенит» фотоаппаратымен өзі түсірген сирек суреттермен қамтамасыз етілуі болып отыр. Николай Павловичті суретке түсіруге үйреткен А.Н. Бернштам экспедициясында бірге болған археология ғылымындағы жақсы танымал маман Л.И. Ремпель болатын.

Түйін сөздер: археология, Н.П. Подушкин, Оңтүстік Қазақстан, Абай атындағы Қазақ пединституты, археолог, мұғалім-педагог, экспедициялар

\section{NIKOLAY P. PODUSHKIN - SCIENTIST, ARCHEOLOGIST, PERSON (to the 90th anniversary since birth)}

\section{A.N. Podushkin}

In 2019 were 90 years since birth of a known archeologist N.P. Podushkin. Career of Nikolay P. began in the Kazakh teacher's college of Abay. The first field practice was a participation in the Southern Kazakhstan archaeological expedition of A.N. Bernshtam. N.P. Podushkin worked in A.Kh. Margulan's expeditions in Central Kazakhstan, I.I. Kopylov's, E.I. Ageeva's, K.A. Akishev's - in the neighborhood of Alma-Ata and also at the south and southeast of the country. In the article are briefly stated main milestones of career of N.P. Podushkin - from the ordinary worker to the chief of group and head of large archaeological expeditions. The second aptitude of N.P. Podushkin was pedagogical activity. At Chimkent pedagogical institute, where he worked since 1956, he taught such key courses as "Archaeology", "Historical study of local lore" and "Ancient history". N.P. Podushkin is an honourable citizen of Shymkent.

Value of the present article is that it is supplied with rare photos made by N.P. Podushkin with Zenit camera. Nikolay P. was trained art of photography in A.N. Bernshtam's expeditions by L.I. Rempel, a famous specialist in archaeology.

Keywords: archaeology, N.P. Podushkin, Southern Kazakhstan, Abay Kazakh pedagogical institute, archaeologist, teacher-mentor, expeditions

\section{REFERENCES}

1. Podushkin, N. P. 1970a. Rannie osedlye poseleniya Arysi (I-VIII v.v.) (Early settled settlements of Arys (I-VIII centuries)): thesis dis. Candidate of historical sciences. Alma-Ata: Ch.Ch. Valihanov History, Archeology and Ethnography Institute (in Russian). 
2. Podushkin, N. P. 1970b. Rannie osedlye poseleniya Arysi (I-VIII v.v.) (Early settled settlements of Arys (I-VIII centuries)): Dissertation Candidate of historical sciences. Alma-Ata: Ch.Ch. Valihanov History, Archeology and Ethnography Institute (in Russian).

3. Podushkin, N. P. 1990. Arheologicheskie pamyatniki Chimkentskoy oblasti (Archaeological monuments of the Chimkent region). Chimkent (in Russian).

4. Podushkin, N. P., Podushkin, A. N. 2003. Ocherki po istorii i kulture Kazahstana (Essays on the history and culture of Kazakhstan). Almaty: "Kazakparat" Publ. (in Russian).

About the Author:

Podushkin Alexander N. Doctor of Historical Sciences, Professor, South Kazakhstan State Pedagogical Institute, Shymkent, Kazakhstan;p_a_n_alex@mail.ru

\footnotetext{
Мүдделер қақтығысы туралы ақпаратты ашу. Автор мүдделер қақтығысының жоқтығын мәлімдейді. / Раскрытие информации о конфликте интересов. Автор заявляет об отсутствии конфликта интересов.

/ Disclosure of conflict of interest information. The author claim no conflict of interest.

Мақала туралы ақпарат / Информация о статье / Information about the article.

Редакцияға түсті / Поступила в редакцию / Entered the editorial office: 16.05.2019.

Рецензенттер мақұлдаған / Одобрено рецензентами / Approved by reviewers: 23.05.2019.

Жариялауға қабылданды / Принята к публикации / Accepted for publication: 30.05.2019.
} 